\title{
Theoretical and Normative Frameworks for Legal Research: Putting Theory into Practice
}

\author{
Sanne Taekema*
}

\section{Introduction}

Legal doctrinal scholarship is not a discipline that can be said to engage in l'art pour l'art. Legal scholars enjoy discussing current affairs and recent cases and take particular pride in seeing their work cited in a judgment or in parliamentary debate. Many legal scholars also justify their research topics by referring to new developments in practice, displaying more interest in the societal relevance than in the academic relevance of their work. However, to assess the quality of legal research as a contribution to the advancement of knowledge, i.e., as science, it is crucial to know how it relates to the approaches and theories in the academic field.

Within legal scholarship, the academic embedding of a research project often takes the form of a summary of the current state of positive law, combining reference to primary sources such as legislation and court cases with reference to handbooks and recent journal articles. What is less clear is how the researchers in question relate to different points of view in their academic field and how they evaluate the previous research done in that field. This is not to say that legal scholars ignore these issues while conducting research but rather that they leave them largely implicit in their writings (Hutchinson \& Duncan 2012, p. 107).

If we compare legal scholarship with related disciplines, the social sciences seem to pay more explicit attention to such issues. ${ }^{1}$ In social sciences, the relationships to existing approaches and theories are usually spelled out in the theoretical framework of the research project. ${ }^{2}$ The theoretical framework gives the context for the research, and it provides the conceptual basis. The idea of a theory in this context refers to a systematized, coherent body of knowledge based on earlier

* Erasmus School of Law, Rotterdam; taekema@law.eur.nl.

Acknowledgments: This article is in large part the fruit of co-teaching and discussion with a number of colleagues. The Research Lab course I teach together with Ellen Hey has been an important site for development of these ideas, and I thank both Ellen Hey and all the participants over the years for their input. I also thank Wibren van der Burg and Bart van Klink for their comments.

1 Most disciplines within the humanities, such as philosophy or literary studies, are also not very explicit about the academic embedding of the research. In philosophy, for instance, a common approach is to use or react to one particular theory rather than situating the research in the broader field.

2 What is said about theory and theoretical frameworks in the social sciences is mostly also true of the natural sciences, which is similarly focused on the connection between theory and empirical research results. I will not discuss natural sciences here. 
(empirical) research. Ideally, the theoretical framework justifies the research question, by showing how the question arises from the gaps or tensions in existing research. Leaving aside purely theoretical research, in the social sciences the theoretical framework provides the support for a descriptive or explanatory question, advancing possible explanations or causes that need to be investigated in empirical work.

If one grants that an explicit theoretical framework is also useful in legal research, an important question is whether it has the same function and should have the same character as in a social science project. One thing to take into account is that the focus of legal doctrinal research is rather different. Legal scholars have a particular way of engaging in descriptive or explanatory work, using an interpretive method (Van Hoecke 2011) and not usually engaging in empirical research. Moreover, many legal research questions are not descriptive or explanatory but normative: they evaluate a legal state of affairs or offer a solution to a legal problem. The latter also gives the framework for the research a different character: it not only needs to show the link to research that has already been done in the academic field or give the concepts to be used, but it also needs to provide the basis for the evaluation or solution. In such a context, rather than a general theoretical framework, it has to be a normative framework. This then raises the further question of defining the exact relationship between theoretical and normative frameworks in the legal context. The concept of a normative framework seems narrower than that of a theoretical framework: while a theoretical framework can provide support for a variety of research questions, a normative framework is specifically needed to provide standards for evaluation.

In this article, the functions of theoretical and normative frameworks for legal research will be investigated and contextualized. The first part of the article concerns these functions directly, answering the question: how do normative frameworks relate to theoretical frameworks more generally in the context of legal research? Using methodological work within social science as an inspiration, in Section 2 the role of theoretical frameworks is explained. In Section 3, a contrast between social science and legal scholarship is used to show that legal research uses normative frameworks in addition to theoretical frameworks. Section 4 presents different kinds of normative frameworks. The second part of the article concerns the background of the discussion on theoretical and normative frameworks. Here the question is: from what theoretical perspective can a close connection between explanatory and normative scholarship be argued for? In Section 5, this question is explained on the basis of the discussion about the links between normativity and description in legal scholarship. In Sections 6 and 7, a particular argument from a pragmatist perspective is advanced on how to understand the relationship between the two, descriptive-explanatory and normative frameworks.

A terminological note at the start: the point of departure for this contribution is legal doctrinal scholarship, understood as academic legal research that focuses on positive law. Often, legal doctrinal scholarship is distinguished from socio-legal and theoretical legal scholarship (Watkins \& Burton 2013) — and then the former is often rather pejoratively referred to as a 'black-letter' approach (e.g., Salter \& 
Mason 2007). However, current academic legal doctrinal work is linked to broader approaches to law in many ways, making it more correct to see the distinction between doctrinal and other legal scholarship as one involving many possible intermediate steps (Vranken 2012; Taekema 2011). It does make sense, however, to make a basic distinction between research that focuses primarily on studying positive law and research that has a broad, 'law and', orientation from the outset such as law and economics, socio-legal studies, legal philosophy or law and literature. Therefore, doctrinal scholarship hereafter will refer to positive-law-oriented research, and legal scholarship will refer to the broader field of academic research from a legal perspective.

\section{The Purposes of a Theoretical Framework}

At the outset, it is necessary to give an account of a theory or theoretical framework. In its most basic form, a theory can be described as a coherent account of a particular phenomenon or aspect of the world. Typically, a theory specifies certain relations between items making up a phenomenon or between a phenomenon and its environment. For example, we could say that a theory of education gives an account of how a student learns, specifying what the influence of teachers, of learning activities and of other students are on the learning process. In order to construct a theory, it is necessary to define its basic concepts and to explain how these concepts relate to each other. Crucially, a theory is an account of something devised by a researcher, or several researchers jointly or consecutively, and is thus itself a construct of the theorist's mind. There is an understandable tendency to see theories as abstract entities, removed from our social reality. It is important to note, however, that the abstraction of theories is highly variable: a theory about law can be as abstract as H.L.A. Hart's account of the legal system as the combination of primary and secondary rules and as concrete as the theory that causation in the context of tort law means a condicio sine qua non.

In the context of legal scholarship, theoretical frameworks are not often addressed, and if they are, it is in the context of methodology discussions. ${ }^{3}$ Usually, research is driven by current developments in doctrinal debate or legal practice, and the fact that there is a problem in the current state of positive law is enough justification for doing research. This has led some scholars to argue that the (implicit) theoretical framework for legal scholarship is the current legal system itself (Westerman 2011). Others contend that the theoretical framework is broader, i.e., that it must include a perspective on the legal system (Vranken 2011). I will return to this point in the next section. The way the role and character of the theoretical framework are sketched depends on the characterization of the discipline of legal scholarship, and thus reflects debates on the character of the discipline (Van Hoecke 2011, p. 3; Vranken 2011, pp. 117-118). In the academic discipline

3 For the Dutch context, see IJzermans 2015 for references and as one of the few sustained attempts to develop this. 
of law, discussion of theoretical frameworks as part of methodology instruction is rare or highly limited. ${ }^{4}$ This is different in the social sciences, where a theoretical framework is a standard element in research instruction (e.g., Maxwell 2013; Babbie 2013). Therefore, the following general discussion is based on social science insights that I deem relevant for legal research as well. I will turn to the specifics of frameworks for legal research at the end of the section and in the next. In the context of research design, theories may have different roles that all relate to the starting point or context of the research project. Because theories can be regarded as a comprehensive point of departure for research and thus framing a project, I will use the term 'theoretical framework' rather than just 'theory' in order to highlight their role in a methodological setting. There are various purposes for which a discussion of a theoretical framework may be included in one's research, and I will highlight three. The first, and possibly most important, purpose of including a theoretical framework is to embed the research project at hand in the state of the art. This means that a description of the theoretical framework shows how the project is related to the work of others. Most simply, this can be a description of previous research results on the same topic. For instance, if the topic is the use of the legislator's intention as a method of constitutional interpretation, it is useful to describe the existing debate on originalism in constitutional interpretation (Barber \& Fleming 2007). Using this example, it is possible to specify further the idea of describing the state of the art: it is an account of the debate between different views on the topic. It is not simply an enumeration of what has been done before, but it is also an account of how these different views and results relate. Although in some areas there is a clear majority view on an issue, in most legal research there are competing points of view providing opposing theories.

This first purpose, of embedding work in the state of the art, may be broader than discussion of a theoretical framework; the state of the art, strictly speaking, need not always concern the theoretical underpinnings of the project, but may also concern previous research results or methodologies. In many research handbooks, this purpose is therefore discussed as being served by a literature review (Blumberg et al. 2008; Randolph 2009). However, a part of such a literature review will usually be devoted to linking the topic to the theories in the field. In this sense, a theoretical framework cannot simply be an account of the state of the art, because the theoretical framework needs to specify how the project itself exactly relates to previous work.

That leads to the second purpose of discussing a theoretical framework: it makes clear to which scholarly tradition a project is connected. A scholarly tradition is understood in a broad sense here: it can be the standard way of conducting research in an academic field or discipline, or it can be a particular theoretical or ideological approach to the topic. Linking to a particular approach is especially

4 This is part of a broader problem of the lack of methodology textbooks that give practical instruction on how to do legal doctrinal research. Books on legal method in English are usually practice oriented (e.g., McLeod 2005), while academic methods books pay more attention to socio-legal research than to doctrinal research (e.g., McConville \& Chui 2007). 
important in academic fields that are characterized by entrenched pluralism. For instance, in international relations there is a long-standing debate between realism, liberalism, critical theory and constructivism (Burchill \& Linklater 2013). In such a field, it is particularly necessary to reflect on the approach to align with. To return to the example of legislators' intentions, there are various ways to approach the issue of constitutional interpretation. It is possible to discuss methods of constitutional interpretation as a matter of constitutional law, focusing on the use of these methods in constitutional cases and their relation to constitutional doctrines, or as a form of legal philosophy, focusing on the theory of legislative intent and the (im)possibility of uncovering this, or as a form of legal reasoning, focusing on the mechanisms to (re)construct legislators' intentions. An important purpose of the theoretical framework is that it makes clear how a project relates to one or more scholarly traditions. If there is a large degree of consensus in the field in question, the state of the art and the scholarly tradition may coincide, but more often, as noted, a particular approach needs to be chosen. For instance, in company law, the role of company management may be explained by using a principal-agent theory, relating managers to shareholders (Jensen \& Meckling 1976). However, a competing theory focuses on stakeholders: seeing management as accountable to various groups, not only to shareholders but also to others such as employees and consumers (Freeman 1984). Although it may be the purpose of one's research to test the explanatory power of one theory over the other, it is often sufficient to use one scholarly approach as the starting point for one's project. In the first example, of constitutional interpretation, the choice of theoretical framework is more a matter of choosing an academic subfield, while in the second example it is a matter of a particular theoretical approach.

Such an approach can be used for the third purpose of a theoretical framework: being a resource for various tools for conducting one's research. Most obviously, theoretical frameworks serve as conceptual frameworks, by providing a set of concepts that can be used for the project. They also provide descriptive links or explanations. Thus, for instance, principal-agent theory provides the two crucial concepts of its name, principal versus agent, and the related idea of agency costs, which provides a particular idea of how principal and agent relate. All of these concepts may be useful in a company law project. Similarly, a theoretical framework may be the starting point for the choice of a certain methodology. Many theoretical frameworks have been developed by using particular methods, and this suggests a close relationship between the theory and the methodological approach used. For instance, if a project is situated in behavioral law and economics, it builds on a theory developed through lab experiments (Sunstein 2000), and a natural way to go ahead is to continue with a new experiment. Similarly, by situating one's research in the tradition of legal anthropology, the value of using an ethnographic method is made plausible.

All of these uses of a theoretical framework are therefore relevant to research design and give context to research questions. The relevance of a research question is shown most clearly if it is justified on the basis of a theoretical framework (Van Hoecke 2011, p. 14). 


\section{From a Theoretical to a Normative Framework}

Borrowing from social science research to explain theoretical frameworks has the advantage of being able to draw on explicit discussions of their role, but there are also drawbacks. These are mostly related to the context of social science as an empirical discipline centering on gathering data. In most social science research manuals, this context is the point of departure. In such social science research, a theoretical framework has a specific role in research design that is distinct from the empirical research to be conducted (Layder 1998; Maxwell 2013). The theoretical and empirical components of the research complement each other: the theory generates a research problem and a possible explanation, which can be tested empirically. In quantitative research especially, this is pictured as a cycle: starting with a theory, which leads to a hypothesis, which leads to empirical observation and analysis, leading back to improvement of the theory, after which the cycle continues with the next round (Corbetta 2003, pp. 57-59). The role of the theoretical framework is less clearly defined if the research is qualitative: there is not always a specific hypothesis that can be tested, and sometimes the research itself is mainly theoretical, not involving an empirical component. Some qualitative research develops the theory after collecting empirical data: for instance, in the approach of grounded theory (Glaser \& Strauss 1967).

In legal research, doing empirical work, in the sense of gathering data about social reality, is not the common approach. ${ }^{5}$ What complicates matters further is that the research questions addressed in legal research may vary considerably. While social science research attempts to answer descriptive and explanatory questions, aiming to explain features of human behavior and society, legal research also attempts to answer evaluative and normative questions. Such questions have a need for a different kind of framework, not one that can explain why law is what it is, but a framework that can provide arguments for a judgment that the law is good or bad. An explanatory theoretical framework does not provide such arguments. To return to the area of company law, knowing why there are incentives in company structures for managers to act in their own interest rather than in the interest of the people they work for does not in itself yield a normative judgment on that structure. If the argument is that companies are legally designed to prevent managers from pursuing their own interests, i.e., arguing that company law has particular goals, one can assess whether these goals are achieved with the present legal structure. This evaluative question needs to be answered on the basis of standards (in this case, the purposes of company law) against which a legal situation can be assessed.

Rather than an explanatory theoretical framework, legal research pursuing normative questions needs a normative framework. Under the broad rubric of normative questions we usually group evaluative questions, assessing the positive or

5 However, empirical legal research is becoming more popular rapidly and is also the subject of methodological work. See, for example, the articles in Law and Method by Van den Bos \& Hulst 2016, Dhami \& Belton 2016, Melville \& Hincks 2016, and Webley 2016. 
negative quality of law, and prescriptive questions, determining what should be done to improve the situation. ${ }^{6}$ These often go together: a judgment that the law is faulty often leads up to a recommendation that the law needs to be improved to correct that fault, but this combination is not necessary. ${ }^{7}$ Evaluative questions can also stand on their own. In order to answer normative questions, a framework is needed that provides a yardstick, a set of standards or values that can serve to support a judgment. For instance, in criminal procedure the principles of fair trial, and the right to a fair trial as laid down in the European Convention on Human Rights, yield standards against which a researcher may assess whether access to an attorney in the early stages of an investigation is sufficiently secured. Unlike theoretical frameworks in social science, which are often a separate topic in methods handbooks, normative frameworks in legal research are hardly discussed. Westerman argues that this is because the legal system is used as the implicit theoretical framework (Westerman 2011, p. 90). On her view, doctrinal legal research is inherently normative and uses the principles of the legal system as standards. This makes the distinction between theoretical and normative framework superfluous: the legal system is both at the same time. In his comment on Westerman, Vranken strongly disagrees with the idea of the system as theoretical framework (Vranken 2011). He sees the legal system as the subject of a range of theoretical perspectives, and the normative principles by which to judge that system as varied too. The question of what can serve as a normative framework is a crucial one, therefore, because it is an important determinant of the plausibility of the answer to a normative question.

\section{Internal and External Framing}

In order to address the issue of finding and developing a normative framework systematically, it is useful to distinguish between internal and external frameworks (Kestemont 2015, p. 373). 'Internal' refers to standards that are part of the law, its principles and values, while 'external' refers to theories that provide such standards. This is not to say that the distinction between internal and external is clear-cut - there are many borderline cases - but it is helpful to survey the terrain. ${ }^{8}$

Looking for internal frameworks means tracing the normative basics within positive law. In most fields of law, certain basic principles and values are stated or presupposed. In private law introductions, students are taught that the freedom of contract and security of property are basic to the private law system and that

6 Van der Burg 2017 distinguishes evaluative questions, such as 'Is the law good?', from normative questions, such as 'How can it be improved?'.

7 Often, recommendations take the form of a suggestion to improve legislation, but they may also concern new ways of interpreting statute or developing case law or the need to recognize a new principle of law.

8 On internal versus external perspectives in legal scholarship, more generally, see Taekema 2011. 
there is a test of fairness or equity in solving concrete disputes. Specific areas of private law have their own principles, such as the protection of consumers or employees or the best interests of the child. What all of these have in common is that they are basic principles that are either explicitly stated or implicitly presupposed in positive law: they are part of the legal system. In public law, the principles of rule of law and human rights have a similar basic function, with fundamental rights being granted a special status in treaties or constitutional bills of rights. These are also seen as foundational elements of positive law. This is not to claim that these principles and values are completely contained in the sources of law: there is controversy in legal theory (between positivism and interpretivism) over the extent to which principles and values can be seen as extending beyond source-based rules and drawing on moral and political values. ${ }^{9}$ However, in both theories it is possible to find or construct principles of law. These basic principles and values easily serve as internal normative frameworks, i.e., as those parts of positive law that yield standards for evaluation. Sometimes, work needs to be done to formulate the implicit principles more clearly in order to apply them, but in many cases the basic material is there in positive law or in earlier formulations in legal doctrine. ${ }^{10}$

However, law is not usually studied in splendid isolation. If law is regarded as reacting to the social and political environment, other goals and values come into play, which are part of external frameworks. Looking at law from a broadly moral external perspective, one might say that law itself must always be assessed according to justice: to what extent does the legal system reproduce social injustices or redress them? In order to develop such a broad ideal into a normative framework, a theory is needed on what principles of equality and freedom support that ideal. For instance, the liberal political theory of John Rawls provides a set of basic principles that can also be used to assess the basic constitutional legal structure (Rawls 1971). Critical theory, which sees injustice as the domination of powerful groups, can similarly be used to assess legal doctrine (Unger 1986). Such external normative frameworks have the advantage that they can serve to criticize the basic principles of a legal system itself, transcending the particular values of a given legal system. Most of these theories have their basis in social or political philosophy. ${ }^{11}$ Unfortunately, this also makes them rather abstract, often showing the need for further refinement if one wants to use them to assess more concrete legal developments.

A more concrete way to discover an external framework is to look for policy aims. Often, political policies are the point of departure for legal reform. For instance, the threat of terrorism has yielded the political aim of enhancing security ser-

9 The classic debate between Hart (1994) and Dworkin (1978) is relevant here, as well as later discussions on inclusive positivism (Waluchow 1994).

10 By legal doctrine I mean the scholarly work done by lawyers to clarify and systematize positive law.

11 Although these theories need not be philosophical, other normative theories, for instance normative economics, may also yield external criteria, such as efficiency (compare Kestemont 2015, p. 374). 
vices, for which new legal powers are created to acquire and retain large amounts of data. One way to evaluate the new law that results from this policy is by going back to the policy aims that generated the law and assessing whether the new law actually realizes these aims. Sometimes, there is a coherent policy theory behind a new law, and often there is not - many legal reforms are the result of less structured bargaining between different interest groups, in which case it may be difficult to reconstruct the political aims behind the law in a coherent manner. There are, however, usually at least some identifiable purposes that a law is meant to serve, and these can be used as standards in a normative framework. When it comes to policy aims or purposes, the distinction between external and internal frameworks may not always be clear-cut: sometimes, the policy aims are integrated in the legal text (for instance, in the preamble of a treaty) or become part of the standard interpretation in case law. A plausible argument can then be made that what were once external goals have become internalized and included in the set of internal standards of the legal system. This may depend on the stage of legal reform: if a reform is planned or has just been implemented, the need to refer to external policy goals is greater. In the context of the discussion here, it is primarily important to stress that external policy aims may be useful building blocks for a normative framework and that it is not necessary to limit the resources for a normative framework to internal legal purposes. ${ }^{12}$

Comparing these different external normative frameworks, a distinction can be made between the more critical philosophical theories, which are based on theoretical arguments for basic values, and the more conventional policy theories, which elaborate on the chosen policy aims at a given time and place. The more critical perspective can, of course, also be applied to the conventional policy goals rather than only to the law that is used to implement these goals. To return to the security example, a political theory of individual freedom can use values of privacy and individual autonomy to criticize extension of the powers of security services. This is not just a criticism of the law itself, but also of the policy goals behind it.

Finally, there is the possibility of combining internal and external normative standards. Ideally, any law is good in terms of both legal values and of social and political values. Thus, it makes sense to combine assessment of a law on the basis of constitutional rights with assessment on the basis of principles of social justice. However, it is usually not feasible to perform such a broad evaluation in one research project (Van der Burg 2017). As long as it is made clear which set of standards is used for the assessment, a more limited evaluation is perfectly acceptable.

12 Again, the question can be raised regarding the sense in which legal purposes are really internal to law (see footnote 8). 


\section{Implicit Standards: Uncovering Normativity in Legal Research}

The consideration of frameworks for legal research offered so far, which were predominantly meant to serve as support for practical research aims, can be contextualized by linking to the scholarly debate on the nature of legal research itself. It is worthwhile to do so in order to make clear how the normativity of practical reason, which underlies the need for normative framing, may be accounted for in legal scholarship. Thus, in this second part, the emphasis shifts from a discussion of the nature and function of theoretical and normative frameworks to the broader question of how to understand the nature of legal scholarship: how may we best understand the connection between descriptive and normative scholarship? As a preliminary step, this section is about the character of legal scholarship as both descriptive and normative.

Legal scholarship has a special position as an academic discipline, because the subject matter to which it applies, law, is predominantly concerned with norms. The practice of law lives and breathes normativity: interpreting norms, making normative judgments, arguing about norms, creating norms, implementing norms, sanctioning norm transgressions - the variety of activities concerning normativity is endless. Although there are a few other academic disciplines that also have this focus on normativity, most notably ethics, with which law shares its orientation on practical reason, legal scholarship is characterized by a dual attitude to law's normativity: it regards it as a matter of social fact, and it regards it as a normative enterprise. By social fact I do not mean that it subscribes to the theory of legal positivism, seeing legal sources as social facts, but rather that the norms of law can be described as part of the social and institutional practice of law. By normative enterprise I mean that legal scholars can also engage in the exchange of normative arguments in law, taking part in the debate about the right normative judgments within legal practice, taking on the role of an adviser to practice. ${ }^{13}$

The dual character of legal scholarship is an important part of the problem of legal methodology: the study of law as an existing practice reveals that it shares the descriptive and explanatory focus of social science; its tendency to make interpretive normative arguments reveals it as a normative humanities discipline such as ethics. ${ }^{14}$ One might say that legal scholars face an identity problem: are they social scientists, normative humanities scholars, or a unique species that blends the two? ${ }^{15}$ I would argue that there is a particular blend of social science and humanities aspects and that legal scholarship does not fully belong to either group (Taekema 2011). It is not fully social scientific, because it does not usually

13 Elsewhere, I have argued that this means that most legal scholarship, doctrinal legal scholarship in particular, takes a moderately internal perspective to law: it takes insights from other disciplines on board, but it remains committed to normative arguments that are addressed to legal practice (Taekema 2011, p. 50).

14 This dual character was argued for by Franken 2004 in the Dutch debate on the nature of legal scholarship.

15 For my own argument on how to combine these, see Sections 6 and 7. 
aim at empirical data collection or at answering explanatory questions. In its own way, it does gather facts, but then one needs to understand fact-gathering more broadly than as empirical data collection. It is not fully part of normative humanities, because its arguments need to be based on descriptions of positive law. It does make its own normative arguments (as discussed earlier, usually based on legal values and principles). I would also claim that most doctrinal legal scholars do not want to choose but are also rather vague about how they see the blend between the two. This shows most clearly in the research aims pursued in legal doctrinal work. Most dissertations, for instance, devote the bulk of their pages to describing the intricate workings of a particular area of law, which, especially in these times of transnational developments, involves a complicated exercise in relating supranational to national law and comparing various national legal systems. However, they also aim to provide recommendations on how the law in this area should be developed, without necessarily making clear how to get from the comparative description to the normative judgment (Siems 2014, pp. 22-23). For instance, knowing what the differences are between German and Dutch implementation of EU consumer law does not automatically provide the basis for recommending that the Dutch use the German implementation as a model.

An important step to take, but one that legal scholars are not really trained in, is to uncover the implicit 'ought' in their research project. To stay with the (fictitious) example, one of the unstated premises of this research on implementation of EU consumer law may be that maximizing consumer protection is best, so that the conclusion of the comparative research that the German system is more advantageous for the consumer would lead to the judgment that the German system is better than the Dutch and should therefore be copied. It is, however, quite crucial to explicate this normative premise: one could also argue that maximal consumer protection is undesirable, for instance because it hampers efficient transactions. Once the unstated premise is made explicit, the question can be asked whether there is a sufficient normative basis, a normative framework, for that premise, or whether an alternative normative framework is preferable.

There is an important caveat, however: the normative aspect of the research needs to remain grounded in the descriptive part. This means that, although it is important to include standards from a normative framework to support the normative judgment, the researcher needs to relate that normative framework to the descriptive results. Again, this is best illustrated by returning to the example. Let us imagine that the comparative research shows that Dutch courts have developed a particular interpretation of EU consumer law that aims for an even balance between consumer interests and the interest of easy business transactions, while the German courts let the consumer interest prevail over the transaction efficiency. Even if the normative framework justifies the German approach, the judgment that this should be introduced in the Netherlands is plausible only if the context of Dutch legal practice is included in the argument. This means that the details of the comparative descriptive work are also highly important to contextualize the normative judgment (compare Siems 2014, p. 221). Of course, one could argue that the normative judgment can stand on its own and that it is enough to say that the Dutch situation must change. However, the practical 
orientation of legal scholarship makes feasibility an important issue. If one wants to advocate change, the chance of success ought to be included; otherwise, the relevance to legal practice will be severely limited.

\section{Reconnecting 'Is' and 'Ought': A Pragmatist Framework}

Having argued that the descriptive and normative components of legal scholarship need to be distinguished yet connected, I now want to broaden the discussion. What kind of theory of the relationship between facts and normativity can back up this characterization of legal research? If social fact and legal norm are seen as belonging to two different perspectives, as has been argued, for instance, by Kelsen, ${ }^{16}$ judgments of facts and judgments of norms cannot be combined, because the logic of the two perspectives is radically different. Theories that relate fact and norm as part of the same scientific enterprise are therefore a more promising route. There are different ways of doing so, ${ }^{17}$ but here I will explore just one possibility, taking pragmatist naturalism as a basis for connecting facts to normativity. Naturalism is an interesting option because it aims to unify investigation of facts and norms and values by linking them to knowledge about the natural world (Papineau 2015). Moreover, naturalist theories propose a joint method of inquiry for factual and normative questions. With the argument in mind that descriptive and normative components of legal scholarship are connected, it seems that naturalism offers a possible way of grounding that connection in a broader theory.

Naturalism can refer to different theories. Although the common core of naturalism is that research needs to be based on an empirical assessment of facts about the world, there are very different ways in which that core can be developed. On the one hand, one can be skeptical about the worth of normative legal research altogether (Holtermann \& Madsen 2016); on the other hand, one can argue that judgments of fact are interrelated with normative judgments (Del Mar 2016). Given the character of legal scholarship as oriented toward practice, it seems important to leave space for law's internal point of view and a role for legal scholarship in debate with practitioners. To achieve this, the ability to take a normative position as a legal scholar is important. Within naturalism, I will therefore explore the pragmatist position that argues that facts and norms are

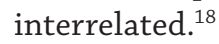

For a discussion of this aspect of Kelsen's theory, see Van Klink and Lembcke 2016, pp. 212-214. Important traditions linking facts and norms in law are hermeneutics (Smith 2011) and interpretivism (Dworkin 1986).

Within the pragmatist literature, the dualism denied is actually that of fact and value (Putnam 2002). However, I would argue that norms and values are part of the same domain in the context of scholarship and that ontologically, norms are a deontological expression of values (i.e., giving standards of conduct needed to realize values). In the context of this article, I will use facts and norms or normativity as the main distinction, including values where necessary. 
In a pragmatist perspective, an important starting point to derive from naturalism is the basic insight that human beings inevitably engage in social practices, which are normative. More particularly, the purposive action of human beings generates practices with a point, i.e. an ideal or value toward which the practice is oriented (Selznick 2008, pp. 55-56). One way to characterize such naturalism is as the claim that the social and purposive nature of humans makes ideal-oriented social practices a naturally arising part of human life (Selznick 2008, p. 41). ${ }^{19}$ Law is one of these ideal-oriented social practices and is hard to understand without its value-orientation. Therefore, one way in which facts and values (as a form of normativity) are related in law is through its character as a naturally arising practice through which people try to realize values. In addition to the natural base of normativity, the relation also goes the other way: a normative focus also influences how one regards facts. This is not to say that all factual judgments are biased, but from a pragmatist point of view, there is an inevitable selectivity and purposiveness to an inquiry into facts. This is because all inquiry, practical or scientific, is driven by a problem-solving orientation. Because of this shared orientation and method, inquiry in practice and in scholarship are only gradually different; they are not completely separate enterprises (Dewey 1988, p. 174). It is because we regard a situation or idea as problematic that we search for facts that help to reconstruct the conditions giving rise to the problem and the consequences that arise from it. Like a theoretical framework, the values attached to a problem give context to an empirical inquiry.

Thus, a crucial connection made between factual and normative aspects of scholarship is the need for context (Del Mar 2016, p. 235): we cannot understand values without investigating the concrete pursuit of those values in practice, i.e., without an understanding of the factual contexts in which values operate.

\section{Humanist Science: Daring to Be Normative}

For most social scientists, normativity is a problematic part of scholarship. Most scholars see norms and values in either of two ways: as something present in the social world that can be studied from an external perspective or as a personal attribute of the scholar him- or herself that gives research a moral flavor. Depending on the importance attached to neutrality as an attribute of good research, researchers may try to retain their external and objective position - a neutral stance - or they may embrace the influence of their own values on their research goals and results - a moral stance. In the context of legal research, the neutral stance leads to a purely descriptive research goal or to a careful hypothetical argument concerning normative questions. By the latter I mean that researchers may argue, for instance, as follows. Supposing that a basic principle of a given legal system is non-discrimination - a supposition buttressed by the fact that it

19 This form of pragmatism has a close affinity to evolutionary thinking. Compare De Been 2008, p. 14. 
is in the constitution or a human rights treaty - the principle may be used as a major premise in an argument that racial profiling by the police is legally wrong. Neutrality is then preserved by using positive law as the basis for the normative argument. The moral stance within law means identifying with the basic values of the legal order and making them your own. In this case, non-discrimination is not just supposed to be part of the particular legal order, it is seen as an integral part of the values a researcher personally affirms. Racial profiling is discriminatory and legally wrong because it violates the morally right principle of non-discrimination, which is fortunately also part of the legal order the researcher works in. I think it is unfortunate that we tend to think about the role of normativity in such an all-or-nothing fashion. The idea of humanist pragmatism challenges this dichotomy and draws attention to the space in between. The most important place for normativity and value judgments in scholarship is in what Martin Krygier termed 'clinical assessment' of a value-laden practice (Krygier 2012, pp. 202-204). Krygier points out that in the work of Philip Selznick the diagnosis of the realization of certain values within society is not strictly neutral: using a normative theory, Selznick assesses the strength of value realization within a certain practice. It is not neutral because the normative theory used is not merely posited but constructed on the basis of theoretical argument, and therefore in part depends on how convincing it is to the scholar himself. The research is, however, closely observant of the factual social situation: only by carefully studying the facts of the social context can one make a good assessment. It is therefore not a personal moral stance that drives the research: it is a scholarly judgment on the way values play out in social practice.

The idea of the clinical assessment of value realization in law can be illustrated by using Selznick's favorite value: the rule of law or legality. Based on a normative theory of the point of the practice of law, Selznick argues that we should understand the rule of law as the commitment to "progressively reduce the degree of arbitrariness in positive law and its administration" (Selznick 1969, p. 18). Using such a notion of the rule of law, it is possible to criticize legal systems for falling short in the realization of that ideal, for instance, if there is insufficient restraint of official discretion in a certain area of law. It may also be used to criticize a legal order more fundamentally, for instance, if a parliament refuses to respect the judgments of a constitutional court on the unconstitutionality of a statute, or changes the constitution to limit the independence of the judiciary. The benefit of such assessments is that they are not limited by the posited values and principles in basic legal documents but can criticize beyond that positive content, using aspects of the normative theory that are tied to the values as formulated within positive law but which reach beyond that.

Some may be skeptical about the possibility to do such normative scholarship without having a personal stake in the norms and values that are used in the assessment. I would argue, however, that there is a subtle difference between personal conviction and the scholarly judgment that a certain normative theory is the most convincing one. The scholarly conviction can be backed by argument and put to the test of scholarly debate; moreover, it is tested in its usefulness to understand and assess particular situations in which norms and values are at 
work. Although an element of personal conviction is part of scholarly judgment - you need to be convinced of a certain theory or belief to hold and defend it scholarly judgment is open to revision on the basis of argument. These arguments may range from the coherence of the normative theory itself to the alignment with explanatory theories of human behavior and society to the concrete applications of the theory in practice. ${ }^{20}$ The philosophical normative theories discussed in section 4 may be used to provide the broader argument for these convictions, but these may be made into the subject of debate themselves: the provisionality of scholarly normative judgment means that one needs to be open to the argument that a theory is untenable for some reason.

\section{Concluding Remarks}

If I connect the discussion of the interplay between empirical and normative aspects of law to the earlier exposition on theoretical and normative frameworks, I would argue that the distinction between theoretical and normative frameworks is not always so clear-cut. Of course, there is a significant difference between a framework supporting questions of explanation and causality and a framework supporting questions of evaluation and normative recommendation. However, researchers who try to do justice to descriptive accuracy as well as normative depth need to connect the two types of framework. A normative framework itself may need to be justified, and such justification will in part depend on explanatory theories of the nature of human beings and societies. Moreover, as argued in section 6 , a good understanding of the values at work in law needs to be grounded in the understanding of the factual and institutional contexts of law.

Making normative standards explicit and paying closer attention to the arguments supporting normative judgments about law is important for the quality of legal research. However, it should not cause legal scholars to forget the close connection between their descriptive work on law and the evaluations they give.

\section{References}

Babbie, Earl (2013). The practice of social research (13 $3^{\text {th }}$ edn.), Belmont: Wadsworth.

Barber, Sotirios A. \& Fleming, James E. (2007). Constitutional interpretation: The basic questions, Oxford: Oxford University Press.

Blumberg, Boris, Cooper, Donald R. \& Schindler, Pamela S. (2008). Business research methods, New York: McGraw-Hill, pp. 106-148.

Burchill, Scott \& Linklater, Andrew (Eds.) (2013). Theories of international relations, Basingstoke: Palgrave Macmillan.

20 One way of trying to combine all these elements in a broad normative theory is the method of wide reflective equilibrium (Daniels 1996). 
Corbetta, Piergiorgio (2003). Social research: Theory, methods and techniques, Thousand Oaks: Sage, DOI http://dx.doi.org.eur.idm.oclc.org/10.4135/9781849209922.n3.

Daniels, Norman (1996). Justice and justification: Reflective equilibrium in theory and practice, Cambridge: Cambridge University Press.

De Been, Wouter (2008). Legal realism regained: Saving realism from critical acclaim, Stanford: Stanford University Press.

Del Mar, Maksymilian (2016). 'The natural and the normative: The distinction, not the dichotomy, between facts and values in a broader context'. In S. Taekema, B. van Klink \& W. de Been (Eds.), Facts and norms in law. Interdisciplinary reflections on legal method (pp. 224-241). Cheltenham: Edward Elgar.

Dewey, John (1988). Reconstruction in philosophy, the middle works, 1899-1924 (Vol. 12). Carbondale: Southern Illinois University Press.

Dhami, Mandeep \& Belton, Ian Keith (2016). 'Statistical analyses of court decisions: An example of multilevel models of sentencing', Law and Method, doi: 10.5553/ REM/.000019.

Dworkin, Ronald (1978). Taking rights seriously, Cambridge, Mass.: Harvard University Press.

Dworkin, Ronald (1986). Law's empire, Cambridge: Belknap.

Franken, Hans (2004). 'Rechtsgeleerdheid in de rij der wetenschappen', Nederlands Juristenblad, pp. 1400-1408.

Freeman, R. Edward (1984). Strategic management: A stakeholder approach, Boston: Pitman.

Glaser, Barney G. \& Strauss, Anselm L. (1967). The discovery of grounded theory: Strategies for qualitative research, Chicago: Aldine.

Hart, H.L.A. (1994). The concept of law ( $2^{\text {nd }}$ edn), Oxford: Clarendon.

Holtermann, Jakob v. H. \& Madsen, Mikael Rads (2016). 'What is empirical in empirical studies of law? A European new legal realist conception', Retford, 39(4), 3-21.

Hutchinson, Terry \& Duncan, Nigel (2012). 'Defining and describing what we do: doctrinal legal research', Deakin Law Review, 17(1), 83-119.

Jensen, Michael C. \& Meckling, William H. (1976). 'Theory of the firm. Managerial behavior, agency costs and ownership structure', Journal of Financial Economics, 4(3), 305360.

Kestemont, Lina (2015). 'A meta-methodological study of Dutch and Belgian PhDs in social security law: Devising a typology of research objectives as a supporting tool', European Journal of Social Security, 17(3), 361-384.

Krygier, Martin (2012). Philip Selznick: Ideals in the world, Stanford: Stanford University Press.

Layder, Derek (1998). Sociological practice: Linking theory and social research, Sage, doi: http://dx.doi.org/10.4135/9781849209946.

Maxwell, Joseph A. (2013). Qualitative research design: An interactive approach ( $\left.{ }^{\mathrm{rd}} \mathrm{edn}\right)$, Thousand Oaks: Sage.

McConville, Mike \& Chui, Wing Hong (2007). Research methods for law, Edinburgh: Edinburgh University Press.

McLeod, Ian (2005). Legal method ( $6^{\text {th }}$ edn), Basingstoke: Palgrave MacMillan.

Melville, Angela \& Hincks, Darren (2016). 'Conducting sensitive interviews: A review of reflections', Law and Method, doi: 10.5553/REM/.000015.

Papineau, David (2015). 'Naturalism'. In Edward N. Zalta (Ed.), Stanford encyclopedia of philosophy (Winter 2016 edn). https://plato.stanford.edu/archives/win2016/entries/ naturalism/.

Putnam, Hilary (2002). The collapse of the fact/value dichotomy and other essays, Cambridge: Harvard University Press. 
Randolph, Justus J. (2009). 'A guide to writing the dissertation literature review', Practical Assessment, Research \& Evaluation, 14(13), 1-13.

Rawls, John (1971). A theory of justice, Cambridge: Belknap.

Salter, Michael \& Mason, Julie (2007). Writing law dissertations: An introduction and guide to conducting legal research, Harlow: Pearson Education.

Selznick, Philip (1969). (with P. Nonet and H. Vollmer) Law, society and industrial justice, New York: Russell Sage Foundation.

Selznick, Philip (2008). A humanist science: Values and ideals in social inquiry, Stanford: Stanford University Press.

Siems, Mathias (2014). Comparative law, Cambridge: Cambridge University Press.

Smith, Carel (2011). 'The vicissitudes of the hermeneutic paradigm in the study of law: tradition, forms of life and metaphor', Erasmus Law Review, 4(1), 21-38.

Sunstein, Cass (Ed.) (2000). Behavioral law and economics, Cambridge: Cambridge University Press.

Taekema, Sanne (2011). 'Relative autonomy. A characterization of the discipline of law'. In Bart van Klink \& Sanne Taekema (Eds.), Law and method. Interdisciplinary approaches to legal research (pp. 33-52). Tübingen: Mohr Siebeck.

Unger, Umberto M. (1986). The critical legal studies movement: Another time, a greater task, Cambridge: Harvard University Press.

Van den Bos, Kees \& Hulst, Liesbeth (2016). 'On experiments in empirical legal research', Law and Method, doi: 10.5553/REM/.000014.

Van der Burg, Wibren (2017). 'The merits of law: An argumentative framework for evaluative judgements and normative recommendations in legal research' (working paper). SSRN: https://ssrn.com/abstract=3020624.

Van Hoecke, Mark (2011). 'Legal doctrine: Which method(s) for what kind of discipline?' In Mark Van Hoecke (Ed.), Methodologies of legal research: Which kind of method for what kind of discipline? (pp. 1-18). Oxford: Hart.

Van Klink, Bart \& Lembcke, Oliver (2016). 'Exploring the boundaries of law: On the Is-Ought distinction in Jellinek and Kelsen'. In S. Taekema, B. van Klink \& W. de Been (Eds.), Facts and norms in law. Interdisciplinary reflections on legal method (pp. 201-223). Cheltenham: Edward Elgar.

Vranken, J.B.M. (2011). 'Methodology of legal doctrinal research: A comment on Westerman'. In Mark Van Hoecke (Ed.), Methodologies of legal research: Which kind of method for what kind of discipline? (pp. 111-121). Oxford: Hart.

Vranken, J.B.M. (2012). 'Exciting times for legal scholarship', Recht en Methode in onderzoek en onderwijs (Law and Method) (2), 42-62.

Waluchow, W.J. (1994). Inclusive legal positivism, Cambridge: Cambridge University Press.

Watkins, Dawn \& Burton, Mandy (2013). (Eds.) Research methods in law, Abingdon: Routledge.

Webley, Lisa (2016). 'Stumbling blocks in empirical legal research: Case study research', Law and Method, doi: 10.5553/REM/.000020.

Westerman, Pauline (2011). 'Open or autonomous? The debate on legal methodology as a reflection of the debate on law'. In Mark Van Hoecke (Ed.), Methodologies of legal research: Which kind of method for what kind of discipline? (pp. 87-110). Oxford: Hart.

IJzermans, Maria (2015). 'Lessen geleerd: onderwerp, object, en theoretisch kader van rechtswetenschappelijk onderzoek', Law and Method, doi: 10.5553/REM/.000013. 